\title{
Isolation and Characterization of L- Asparaginase Producing Endophytic Bacteria from Simarouba Gluaca
}

\author{
Pathuppilly Satheesan Kavya, Parakkottil Chothi Madhu* \\ Center for Biotechnology Engineering, MET'S School of Engineering, Thrissur, India \\ Email address: \\ madupc2014@gmail.com (P. C. Madhu) \\ ${ }^{*}$ Corresponding author

\section{To cite this article:} \\ Pathuppilly Satheesan Kavya, Parakkottil Chothi Madhu. Isolation and Characterization of L- Asparaginase Producing Endophytic Bacteria \\ from Simarouba Gluaca. International Journal of Animal Science and Technologyh. Vol. 3, No. 1, 2019, pp. 1-6. \\ doi: $10.11648 /$ j.jjast.20190301.11
}

Received: November 10, 2018; Accepted: January 14, 2019; Published: February 7, 2019

\begin{abstract}
Cancer cells differentiate themselves from normal cells in diminished expression of L-asparaginase. It is the enzyme that catalyzes the hydrolysis of L-Asparagine to L-aspartic and ammonia, because of these it is used as a medication and in food manufacturing. As a medication L-aspraginase is used to treat various types of leukemia such as, acute lymphoblastic leukemia, acute myeloma leukemia and non Hodgkin's lymphoma. Hence they are not capable of producing Lasparaginase and mainly depend on the L-asparagine from circulating plasma pools. The clinical action of this enzyme is attributed to the reduction of L-asparaginase, since tumor cells unable to synthesis these amino acids are selectively killed by L-asparaginase depravation. This enzyme is widely distributed, being found in as it is widely distributed bacteria as well as found in animals, microbes and plant sources. In the present study L-asparaginase producing bacteria was isolated from Simarouba glauca. It was grown on the modified M9 medium in which L- asparagine was the major source of L- asparaginase production was detected by the formation of pink colored zones on the medium. After the partial purification of the LAsparaginase enzyme, the enzyme activity was found to be 155.83 Units $/ \mathrm{ml}$ and specific activity of 779.15 . The optimum $\mathrm{pH}$ was to be found at $\mathrm{pH} 8$ at a temperature of $37^{\circ} \mathrm{C}$ in the presence of $10 \mathrm{mM} \mathrm{Mg}^{2+}$. The molecular identification was done by16S rDNA, PCR and sequence analysis by BLAST further confirmed that Bacillus cereus.
\end{abstract}

Keywords: L-Asparaginase, Simarouba Glauca, Bacillus Cereus, Enzyme Specific Activity, Cancer Cells

\section{Introduction}

Cancer is characterized by uncontrolled and invasive growth of cells. These cells may spread to other parts of the body and this is called metastasis. It can be controlled by using many enzyme drugs. Now a day's many enzymes used as drugs and L-Asparaginase is one among them. LAsparaginase belongs to the family of amidohydrolase. It is the first enzyme with anti-leukemic activity to be intensively studied in human beings [1]. The enzyme is present in many animal tissues, bacteria, plants and in small mammals. Lasparaginase is widely used in the treatment of leukemia and other lynmphoproliferative disorders. Cancer cells differentiate themselves from normal cells in diminished expression of L-asparaginase. It has established itself to be an indispensable component. Normal cells can synthesize asparagine by themselves whereas cancer cells cannot. Thus they need an additional supply of asparagine in plasma and tissues especially the leukemic cells. L-asparaginase, the enzyme that catalyzes the hydrolysis of L-Asparagine to LAspartate and ammonia Table 1 the conversion of asparagine to L-aspartic acid and ammonia. Because of these it is used as a medication and in food manufacturing. As a medication $\mathrm{L}$-aspraginase is used to treat various types of leukemia such as, acute lymphoblastic leukemia, acute myeloma leukemia and non Hodgkin's lymphoma. Hence they are not capable of producing L-asparaginase and mainly depend on the Lasparagine from circulating plasma pools. This catalytic reaction is essentially irreversible under physiological conditions. The clinical action of this enzyme is attributed to the reduction of L-asparaginase, since tumor cells are unable to synthesis these amino acids are selectively killed by Lasparaginase depravation. The L-asparaginase destructs the free source of asparagine and resulting in killing of cancerous 
cells.

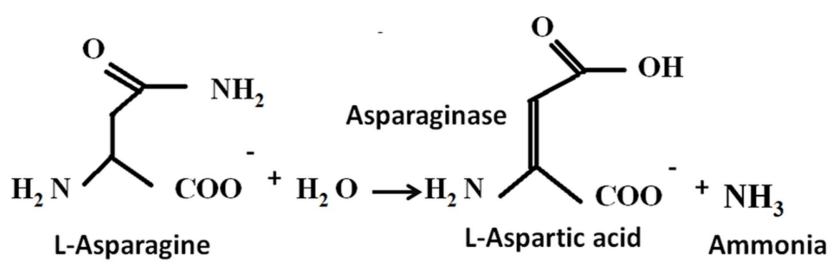

Figure 1. Schematic representation of L-asparaginase reaction.

The present study, L-asparaginase enzyme is produced from Bacillus species which sustain as endophytes in certain species of plants which have anticancer activity. The main example coming under this group is that Simarouba gluaca, which is also known as "Lakshmi taru", "paradise tree" or dysentery-bark". Recent researches showed that the leaf of this particular plant showing anticancerous activity along with antioxidant activity. The leaf extract of these plants showing asparaginase activity. Hence it could be a great source material for isolating endophytic bacteria with bioactive metabolites. Simarouba gluaca leaf decoction when taken in limited amounts can raise the immunity, reduce appetite and increase quality of life in cancer patients. There are different sources of materials were used for the isolation L-asparaginase. But the enzyme isolated from different species will have different physiological, pharmacological and serological properties. Common species that produces Lasparaginase are Erwinia corotovora and E.coli. LAsparaginase is also produced from the Bacillus species [2].

Based on the previous reports, L-asparaginase is remarkably effective in cancer therapy, such as acute lymphoblastic leukemia. The enzyme cuts off the supply of asparagine in the blood stream and the cell death occurs due to the scarceness of the cell's proteins. In this study, we isolated an endophytic bacterium which is capable of producing L-asparaginase, an enzyme showing anticancer activity from Simarouba gluaca leaves.

\section{Materials and Methods}

\subsection{Sample Collection}

The leaf samples were collected in a sterile polythene bag from the local areas of Thrissur District and transferred immediately to the laboratory for the isolation of bacteria.

\subsection{Isolation and Screening of Organism}

The bacteriological studies were carried out by serial dilutions followed by plating on Modified M9 medium and later this culture were used for further studies based on their morphological and biochemical characteristics as out lined in the Bergey`s Manual of determinative bacteriology [3].

\subsection{Submerged Fermentation of Enzyme}

The bacterium, which is capable of producing enzyme, was inoculated into $50(\mathrm{ml})$ of the production media containing substrate L-asparagine- $1 \%$, Glucose $-0.2 \%$, $\mathrm{KH}_{2} \mathrm{PO}_{4}-0.0152 \%, \mathrm{KCl}-0.052 \%, \quad \mathrm{MgSO}_{4} .7 \mathrm{H}_{2} \mathrm{O}-$ $0.052 \%, \mathrm{CuNO}_{3} .3 \mathrm{H}_{2} \mathrm{O}-0.003 \%, \quad \mathrm{ZnSO}_{4} .7 \mathrm{H}_{2} \mathrm{O} \quad-0.005 \%$, $\mathrm{FeSO}_{4} .7 \mathrm{H}_{2} \mathrm{O}-0.003 \%$ and $\mathrm{pH}$ should be adjusted to 6.2 and sterilize the medium by autoclaving at $121^{\circ} \mathrm{C}$ for $15 \mathrm{~min}$. Inoculate $100 \mu \mathrm{l}$ of overnight culture (OD of 0.23 ) incubate at $37^{\circ} \mathrm{C}$ for $72 \mathrm{hs}$. in orbital shaker at $120 \mathrm{rpm}$. Centrifuge the culture at $12,000 \mathrm{rpm}$ for 10 minutes at $4^{\circ} \mathrm{C}$ in order to obtain the enzyme. The supernatant was collected in vials and estimated enzyme activity and enzyme solution was stored at $4^{\circ} \mathrm{C}$.

\subsection{Quantification of Total Protein and Enzyme Assay}

Total protein can be estimated Lowry's method which was read at $660 \mathrm{~nm}$ and BSA used as a standard protein. [4]. The enzyme assay involves the estimation of amount of ammonia released during the enzymatic reaction. Reagent A: $50 \mathrm{mM}$ Tris Buffer, $\mathrm{pH}$ 8.6, Reagent B: $189 \mathrm{mM}$ L-Asparagine, Reagent C: $\left.6 \mathrm{mM}\left(\mathrm{NH}_{4}\right)_{2} \mathrm{SO}_{4}\right)$, Reagent D: $1.5 \mathrm{M}$ TCA, Reagent E: Nesseler's reagent, Reagent F: Enzyme Solution

\subsection{Partial Purification by Ammonium Sulfate}

For the partial purification of enzyme, $75 \mathrm{ml}$ of enzyme was taken and $36.6 \mathrm{~g}$ ammonium sulfate was added to attain $80 \%$ saturation. The precipitate was collected by centrifugation and dissolved in $3 \mathrm{ml}$ of $0.5 \mathrm{M}$ sodium acetate buffer at pH4.7. It was dialyzed against $0.005 \mathrm{M}$ sodium acetate buffer at $\mathrm{pH} 4.7$.

\subsection{Enzyme Characterization}

The enzyme characterization is done by estimating different factors influencing the enzyme activity. The activity of $\mathrm{L}$-asparaginase depends on the various factors such as $\mathrm{pH}$, temperature, substrate concentration and metal concentration.

\subsection{Effect of pH in Enzyme Activity}

The activity of majority of enzymes is often limited within a narrow $\mathrm{pH}$ range. The $\mathrm{pH}$ at which an enzyme exhibits maximum activity is referred as the optimum $\mathrm{pH}$. The effect of $\mathrm{pH}$ on enzyme activity could be ascribed to a number of factors i) the $\mathrm{pH}$ may alter the ionization state of the reactants ii) enzyme might inactivated iii) $\mathrm{H}^{+}$may be involved in the reaction and thus alter the equilibrium position of the reaction iv) $\mathrm{pH}$ might alter the ionization state of the side chains of amino acids essential for catalysts. Dependency from $\mathrm{pH}$ was analyzed by incubation of substrate and enzyme with various $\mathrm{pH}$ buffers from $\mathrm{pH} 4$ to 10 . Assay was conducted at $37^{\circ} \mathrm{C}$ and reaction was stopped by heating at high temperature for few minutes.

\subsection{Effect of Temperature}

Rate of chemical reaction is increased by temperature and also the rate of enzyme catalyzed reactions increase with increasing temperature and extend of enhancement depends upon the energy of activation. The effect of temperature can 
be used to determine the energy of enzymes catalyzed reaction. However, since enzymes are proteins and their typical tertiary structure of enzymes very much affected by temperature, a majority of enzyme proteins are denatured by temperature. Besides temperature, the loss of enzymes activity of enzyme depends upon the experimental conditions, constituents present in the solution and the length of incubation time.

To verify the thermal stability, the concentrated proteins were incubated at different temperature conditions for 15 min. various temperature conditions for the assay are $20^{\circ} \mathrm{C}$ to $60^{\circ} \mathrm{C}$. The reactions were inactivated at high temperature for few minutes and the product formation was monitored by enzyme assay.

\subsection{Effect of Cofactors in Enzyme Activity}

The enzyme assay was carried out at different monovalent and bivalent cations such as $\mathrm{Na}^{+}, \mathrm{K}^{+}, \mathrm{Zn}{ }^{++}, \mathrm{Mg}^{++}$ respectively with concentration of $10 \mathrm{mM}$.

\section{Molecular Characterization of Bacterial Isolates}

The genomic DNA was isolated and visualized by $0.8 \%$ of agarose gel electrophoresis. Polymerase chain reaction was carried out for amplifying the DNA. The genomic DNA was amplified using the primers; 16S Forward Primer: 5'-GAG TTT GAT CCT GGC TCA G-3' and 16S Reverse Primer: 5'G(AT)A TTA CCG CGG CGG CTG-3'.

Initial denaturation was done at $94^{\circ} \mathrm{C}$ for 3 minutes and followed by 30 cycles of denaturation at $94^{\circ} \mathrm{C}$, annealing at $48^{\circ} \mathrm{C}$ for 30 seconds, primer extension at $72^{\circ} \mathrm{C}$ for 30 seconds and final extension at $72^{\circ} \mathrm{C}$ for 7 minutes. The PCR product was then visualized on $0.8 \%$ agarose gel. The PCR a product was cleaned up using ethanol precipitation and the cleaned up products was sequenced using Big dye Terminator sequencing kit. The cleaned up PCR products was sequenced in Applied Biosystems AB 3730XLcapillary sequencer at the sequencing facility. The obtained sequences were then used for similarity searching using Basic Local Alignment Search Tool (BLAST) from National Centre for Biotechnology Information.

\section{Results and Discussions}

\subsection{Isolation and Identification of Organism}

L-asparaginase producing bacteria were isolated from Simarouba gluaca leaves by using modified M9 medium. The bacteria were able to produce pink colored colonies were selected as potent organism. L-asparaginase enzyme can be produced from the Bacillus species which sustain as endophytes in certain plants which have anticancer activity. Certain endophytic bacteria are present inthe Simarouba gluaca leaves and the decoction of Simarouba gluaca were also used in traditional medicine in the treatment of cancer and tumors. It can also be used to complement in modern cancer treatment. Simaroubagluca is very effective in reducing the size of tumors and secondary infections in cancer patients. Thus the medicinal plant could be a great source of material for the isolation of endophytes with bioactive metabolites. [4]. Figure 2 shows the typical plant of Simarouba gluaca.

Bacteriological identification were carried out by gram staining as well as biochemical tests and the potent organism were identified as Bacillus cereus and the molecular characterization were carried out by blast analysis were confirmed that Bacillus cereus. Figure 3 shows the gram staining of Bacillus cereus.

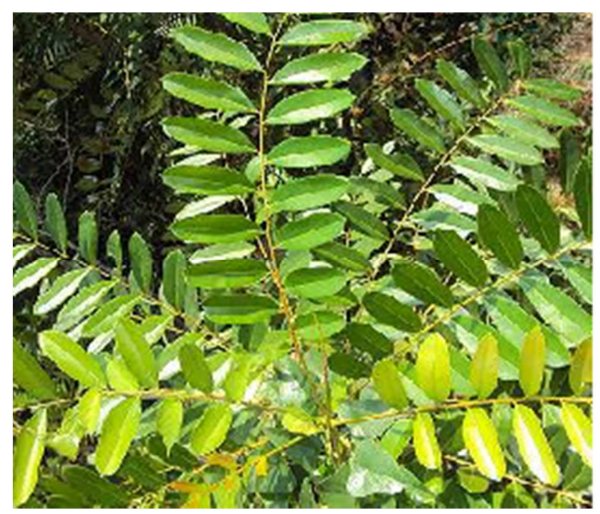

Figure 2. Shows the typical plant of Simarouba gluaca.

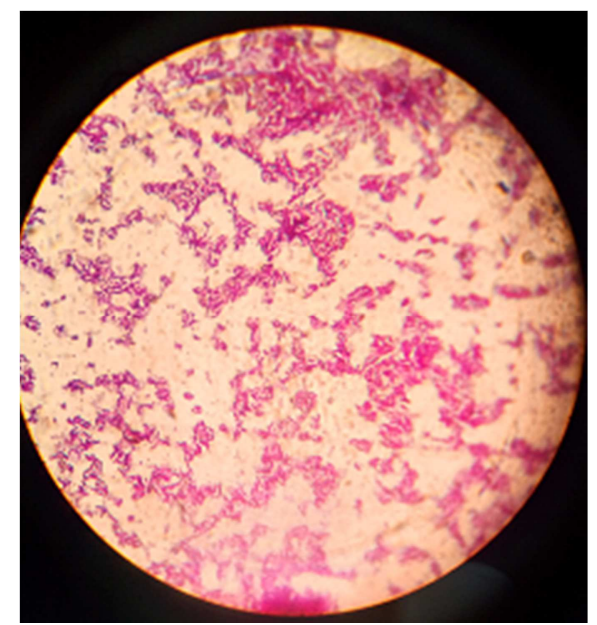

Figure 3. Shows the gram staining of Bacillus cereus

\subsection{Enzyme Quantification}

The enzyme assay were carried out by using asparagine as a substrate, the enzyme activity was determined by the amount of ammonia released when react with asparagine this result compared with based on the standard graph of ammonia. The enzyme activity was calculated using according to standard procedure explained in the previous references. [5]. The enzyme activity was found to be 155.83 $\mathrm{U} / \mathrm{ml}$, the specific activity was 779.15 . Table 1 shows the list of total protein, enzyme activity and specific activity of the purified asparginase. Common bacterial species were produces L-asparaginase are Erwinia corotovora and E.coli. 
Varieties of asparaginase are produced from fungi, Basidomycetes and small mammals like hedgehogs. However, L-asparaginase produced from Erwinia corotovora has been very much useful in clinical trials. L-asparaginases from Erwinia and E. coli have been reported as effective drugs in the treatment of acute lymphoblasticleukemia. [6,7]. L-asparaginase is also produced from the Bacillus species [8]. It is a genus of gram-positive, rod-shaped bacteria and a member of the phylum Firmicutes. Bacillus species can be obligate aerobes (oxygen reliant) or facultative anaerobes. It includes both free-living (non-parasitic) and parasitic pathogenic species.

Table 1. Enzyme activity, total protein and specific activity.

\begin{tabular}{lll}
\hline Total protein & Enzyme activity & Specific activity \\
\hline $0.2 \mathrm{mg} / \mathrm{ml}$ & $155.83 \mathrm{U} / \mathrm{ml}$ & 779.15 \\
\hline
\end{tabular}

\section{Enzyme Characterization}

\section{1. $\mathrm{pH}$}

The enzyme assay was carried out at different $\mathrm{pH}$ by changing the $\mathrm{pH}$ of the buffer in order to found the maximum enzyme activity. The maximum enzyme activity was observed at an optimum $\mathrm{pH}$ of $\mathrm{pH} 8$. Figure 4 shows the optimum $\mathrm{pH}$ of the purified enzyme. A novel and semimicroorganism can produce asparginase and having medicinal activity. A pH and dye-based fast procedure used for screening L-asparaginase producing micro-organisms. The procedure is suitable for bacterial and fungal screening. [9]. It is generally observed that L-asparaginase production is accompanied by an increase in $\mathrm{pH}$ of the culture filtrates. The plate assay was devised using this principle by incorporating the $\mathrm{pH}$ indicator phenol red in the medium containing asparaginase. Phenol red at acidic $\mathrm{pH}$ is yellow and alkaline $\mathrm{pH}$ turns pink, thus a pink zone is formed around the microbial colonies producing L-Asparaginase. [9]. Lasparaginase activity was studied as a function of $\mathrm{pH}$ in range between 4.5-10.5. L-asparaginase was active over broad $\mathrm{pH}$ ranges (4.5-10.5). The enzyme activity increase gradually till pH 8.5 with maximum activity 20.932 IU (relative activity, $100 \%$ ). At higher pH's, enzyme. [10].

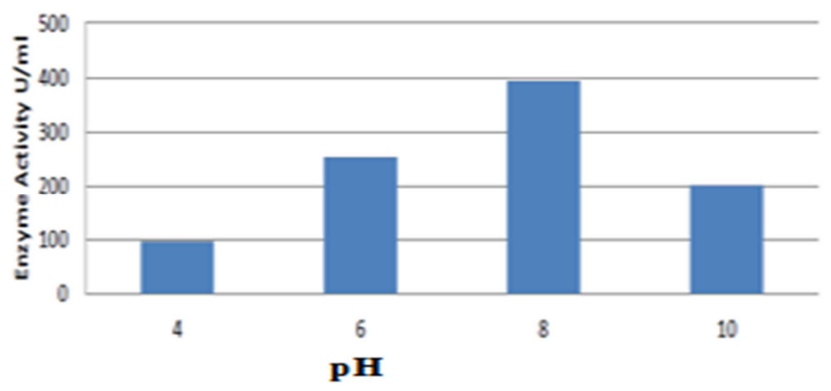

Figure 4. Optimum $\mathrm{pH}$.

\subsection{Temperature}

The temperature assay was carried out at different incubation temperatures to find out the optimum temperature.
The temperature influences the rate of chemical reaction thus affecting the rate of enzyme activity.

The enzyme has showed maximum activity at $50^{\circ} \mathrm{C}(265$ $\mathrm{U} / \mathrm{ml}$ ). Figure 5 shows optimum temperature. A slight decrease in enzyme activity was observed at $40^{\circ} \mathrm{C}(249$ $\mathrm{U} / \mathrm{ml}$ ). [11]. The bacterial flora that associated with an intertidal marine alga (Sargassum sp.), by the presence of extracellular L-Asparaginase; one out of five Bacillus strains was found positive and confirmed that it can produce the enzyme asparaginase. The maximum asparaginase activity was found at $37^{\circ} \mathrm{C}$ and $\mathrm{pH}$ 8.0. The optimum $\mathrm{NaCl}$ concentration for enzyme activity was found to be $2 \%(\mathrm{w} / \mathrm{v})$. The enzyme activity was not affected by the addition of different metal ions $\left(\mathrm{Ca}^{2+}, \mathrm{Co}^{2+}, \mathrm{Fe}^{2+}\right.$ and $\left.\mathrm{Mg}^{2+}\right)$ but strongly inhibited by EDTA. [12].

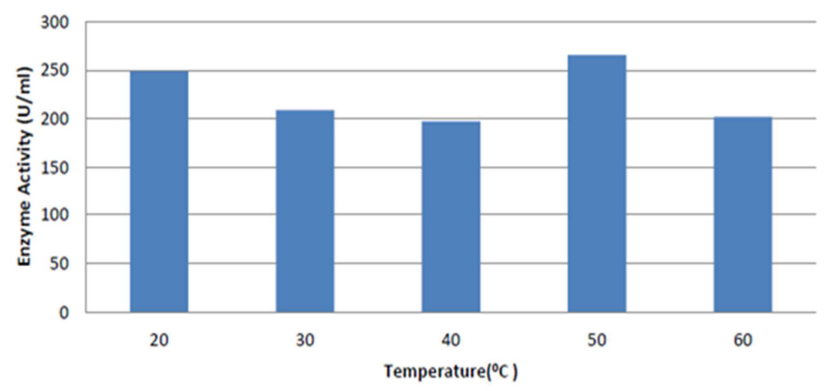

Figure 5. optimum temperature.

\subsection{Substrate Concentration}

The assay was carried out at different substrate concentration (L-asparagine) such as $0.5 \%, 1 \%, 1.5 \%$ and $2 \%$ respectively.

The maximum activity of asparaginase enzyme was found at a substrate concentration of $1 \%(485.83 \mathrm{U} / \mathrm{ml})$. Figure 6 shows effect of substrate in enzyme activity. The activity of L-asparginase of Streptomyces fradiae was evaluated at different levels of $\mathrm{pH}$, temperature, effect of substrate concentration and incubation time. [10].

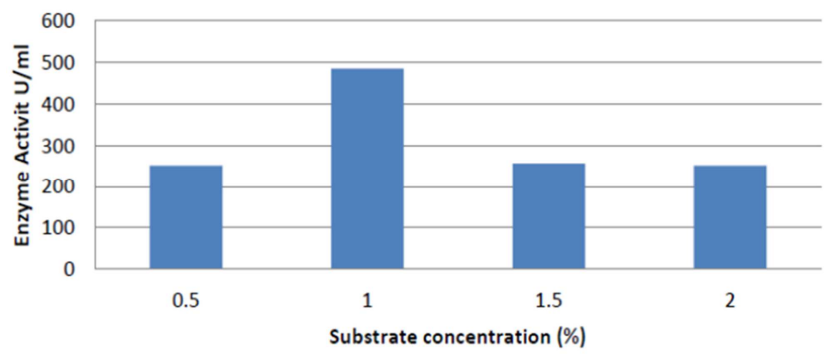

Figure 6. effect of substrae in enzyme activity.

\subsection{Metal ion Concentration}

The assay was carried out at different metal ion concentrations. Monovalent metal ions such as $\mathrm{Na}^{+}$and $\mathrm{K}^{+}$ and divalent ions such as $\mathrm{Zn}^{2+}$ and $\mathrm{Mg}^{2+}$ were used.

The enzyme shows maximum activity with $\mathrm{Mg}^{+}$ions (467.5 U/ml) Figure 7 shows effect of metal ion in enzyme activity. While it shows minimum activity with $\mathrm{Na}^{+}$ions 
(270.4 U/ml) [13]. Screening of the bacterial flora associated with an intertidal marine alga (Sargassum sp.) for the presence of extracellular L-Asparaginase out of five Bacillus strains was found positive. The maximum Asparaginase activity was found at $37{ }^{\circ} \mathrm{C}$ and $\mathrm{pH} 8.0$. The optimum $\mathrm{NaCl}$ concentration for enzyme activity was found to be $2 \%(\mathrm{w} / \mathrm{v})$. The enzyme activity was not affected by the addition of different metal ions (Ca2+, $\mathrm{Co}_{2}+, \mathrm{Fe}_{2}+$ and $\mathrm{Mg}_{2}+$ ); but strongly inhibited by EDTA.

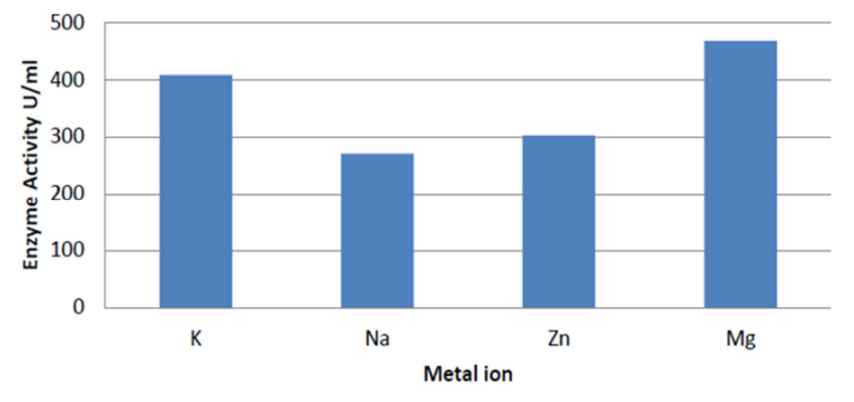

Figure 7. Effects of metal ions in enzyme activity.

\section{Discussion}

L-asparaginse has grown considerably since this enzyme was found to have antitumor activity. L-asparaginase is an enzyme that catalysis the hydrolysis of asparagine to aspartic acid and finally to ammonia. The therapeutic use of this enzyme was responsible for emission in most patients suffering from acute lymphoblastic leukemia. L-asparaginase is the first enzyme with anti-leukemic activity to be intensively studied in human beings since the extraction form human cell is difficult and microorganism have proved to be a better alternative for L-asparaginase extraction. Endophytes are present ubiquitously in all plants species and get importance for their ability to produce various bioactive compounds. It has been reported earlier that some of the endophytic bacteria belongs to members of diverse genera namely Pseudomonas and Bacillus. In recent years there are constant researches on Simarouba gluca in inhibiting the metastasis and invasion of breast cancer tumors according to local Ayurveda practitioners. Maybe because of the reason the leaf of this plant is having anticancerous activity. Detailed studies require proving this data.

\section{Conclusion}

The endophytic bacteria were isolated from Simarouba glauca and it was identified as Bacillus species which have anti-cancerous activity as well as antioxidant activity. Hence it could be great source for isolating such endophytic bacteria. Studies of various parameters such as $\mathrm{pH}$, temperature, substrate and metal ion concentration were found to be the enzyme has the maximum enzyme activity at $\mathrm{pH} 8$ at a temperature of $50^{\circ} \mathrm{C}$ in the presence of bivalent cation such as $\mathrm{Mg}^{++}$. Hence the present study can concluded that the Bacillus cereus isolated from Simarouba glauca producing L-asparinase and having the activity of
$155.83 \mathrm{U} / \mathrm{ml}$ and specific activity of 779.15 . The leaf extracts of Simarouba glauca showing L-asparginase activity data not published. This showed that the plant may carry the gene for the production L-asparginase (Parakkottil Choth Madhu et al data not published). It can also be used to complement in modern cancer treatment. The leaf extract of this plant is very effective in reducing the size of tumors and secondary infections in cancer patients. Thus the medicinal plant could be a great source of material for the isolation of endophytes with bioactive metabolites. It can use for the large scale production Lasparaginase and purified enzyme can be sued for the anticancer activity as well as antioxidant activity. The overall results were provided evidence of antioxidant and anticancer activities of L-asparginase isolated from endophytic Bacillus. The selectivity of this organism proved to be a promising anticancer potential producing by $\mathrm{L}$ asparaginase. However, the research for new lead compounds from bacterial source with more effective and less toxic compounds constitute interesting alternatives for the development of anticancer drugs in cancer treatment.

\section{References}

[1] Savitri, Neeta Asthanan and Wamik Azmi (2002). Microbial L-asparginase: a potent antitumor enzyme Indian journal of Biotechnology Vol:2 pp $184-194$.

[2] Joshi S R, and Fenella M War Nongkhlaw (2015). Laspargnese and antioxidant activity endophytic associated bacteria with ethanomedical plants, Indian journal of Biotechnology pp $59-64$.

[3] Buchanan. R. G and Gibbons. N. E. (1975) Bergey's Manual of Determinative Bacteriology $8^{\text {th }}$ ed., Williams and Wikins Baltimore Inc Baltimore 2 md USA.

[4] Lowry O H, Rosebrough N J, Farr A L, Randall R J. (1951). Protein measurement with the Folin phenol reagent. Biol Chem. (1):265-75.

[5] Salini Dinesh, Devi Soorya Narayana Sasikumar, Bala Girija, Lakshmipriya V. Panicker, Pooja Vinod Kumar, Sruthy Preetha, Shaima Santhilal Sarma (2017) Pharmacological evaluation of endophytic Penicillium pimiteouiense SGS isolated from Simarouba glauca DC, Journal of Applied Pharmaceutical Science Vol. 7 (09), pp. 142-147.

[6] John C. Wriston, AsparaginaseMethods in Enzymology. (1970). Volume 17, Part A, Pages 732-742.

[7] Gulati R, Tsodikov A, Etzioni R, Hunter-Merrill RA, Gore JL, Mariotto AB, Cooperberg MR (2014) Expected population impacts of discontinued prostate-specific antigen screening, Cancer. 15;120 (22):3519-26.

[8] Mohapatra, B. R. \& Sani, Khairul \& Banerjee, U. C. (2008). Characterization of L-asparaginase from Bacillus sp. isolated from an intertidal marine alga (Sargassum sp.). Letters in Applied Microbiology. 21. 380 - 383. 10.1111.

[9] Arif, H M Hussain Z (2014) important sources and medical applications of L-aspargenase. Int J Pharm Sci Rev, 3 35-45. 
[10] Noura El-Ahmady El-Naggar, Sahar F. Deraz, Hoda M. Soliman, Nehal M. El-Deeb, Sara M. El-Ewasy. Purification, characterization, cytotoxicity and anticancer activities of L-asparaginase, anti-colon cancer protein, from the newly isolated alkaliphilic Streptomyces fradiae NEAE82 BMC Pharmacology and Toxicology Sept 2016.

[11] Gulati R, Saxena R K, Gupta R. A (1997). Rapid plate assay for screening L-asparaginase producing micro-organisms. Lett Appl Microbiol. 24(1):23-6.
[12] Zahid H, Ali H, Soudan H, Embaby A, Farag A, Hussein A, Ataya F (2018). Molecular cloning, structural modeling and production of recombinant Aspergillus terreusl. asparaginase in Escherichia coli. Int. J. Biol. Macromol. Jan; pp 1041-1051.

[13] Renuka D Joshi, Nikhilesh S Kulkarni (2006). Optimization studies on L-asparaginase production from endophytic Bacteria, International Journal of Applied Research 2016; 2(3): 624-629. 